\title{
Complete genome sequence analysis of Archaeoglobus fulgidus strain 7324 (DSM 8774), a hyperthermophilic archaeal sulfate reducer from a North Sea oil field
}

\author{
Nils-Kåre Birkeland $^{1 *}$ (D) Peter Schönheit ${ }^{2}$, Lianna Poghosyan ${ }^{1}$, Anne Fiebigi, ${ }^{3,4}$ and Hans-Peter Klenk $k^{3,5}$
}

\begin{abstract}
Archaeoglobus fulgidus is the type species of genus Archaeoglobus Stetter 1998, a hyperthermophilic sulfate reducing group within the Archaeoglobi class of the euryarchaeota phylum. Members of this genus grow heterotrophically or chemolithoautotrophically with sulfate or thiosulfate as electron acceptors. Except for A. fulgidus strain 7324 and the candidate species "Archaeoglobus lithotrophicus", which both originate from deep oil-fields, the other members of this genus have been recovered from marine hydrothermal systems. Here we describe the features of the A. fulgidus strain 7324 genome as compared to the A. fulgidus VC16 type strain. The $2.3 \mathrm{Mbp}$ genome sequence of strain 7324 shares about $93.5 \%$ sequence identity with that of strain $\mathrm{VC}^{\top} 6^{\top}$ but is about $138 \mathrm{Kbp}$ longer, which is mostly due to two large 'insertions' carrying one extra cdc6 (cell-cycle control protein 6) gene, extra CRISPR elements and mobile genetic elements, a high-GC ncRNA gene ( $\mathrm{hgcC}$ ) and a large number of hypothetical gene functions. A comparison with four other Archaeoglobus spp. genomes identified 1001 core Archaeoglobus genes and more than 2900 pan-genome orthologous genes.
\end{abstract}

Keywords: Anaerobic, Hyperthermophile, Sulfate reduction, SRB, Petroleum, Oil-field

\section{Introduction}

Archaeoglobus fulgidus strain 7324 was recovered from hot oil-field water originating from a deep oil-well in the North Sea [1]. It shares many features with the A. fulgidus type strain VC16, e.g. dissimilatory sulfate reduction, utilization of lactate and pyruvate as carbon sources, irregular coccoid to disc-shaped cells, and blue-green fluorescence under the UV microscope due to the presence of Coenzyme $\mathrm{F}_{420}$. Strain $\mathrm{VC} 6^{\mathrm{T}}$ was isolated from a shallow marine hydrothermal system at Volcano island, Italy [2]. The complete genome sequence of strain $\mathrm{VC} 6^{\mathrm{T}}$ was reported in 1997 as the third archaeal genome to be fully sequenced [3] and A. fulgidus has since served as a prototype for studies of archaeal and hyperthermophilic sulfate reduction [4]. Here we report a summary of the features of A. fulgidus strain 7324, together with the

\footnotetext{
* Correspondence: nils.birkeland@uib.no

${ }^{1}$ Department of Biology, University of Bergen, P.O. Box 7803, NO-5020

Bergen, Norway

Full list of author information is available at the end of the article
}

description of the complete genomic sequencing and annotation and comparison with the genome of the A. fulgidus type strain and other Archaeoglobus spp.

\section{Organism information \\ Classification and features}

Genus Archaeoglobus comprises five validly published species; A. fulgidus [2], Archaeoglobus profundus [5], Archaeoglobus veneficus [6], Archaeoglobus infectus [7], Archaeoglobus sulfaticallidus [8], and one candidate species termed "Archaeoglobus lithotrophicus" [9]. All are hyperthermophilic sulfate-reducers capable of heterotrophic or chemolitoautotrophic growth on $\mathrm{H}_{2}$ and $\mathrm{CO}_{2}$. The Archaeoglobus 'clade' also encompasses a few non-sulfate reducing anaerobic hyperthermophiles; Geoglobus acetivorans [10] and "Geoglobus ahangari" [11, 12], which are both Fe(III) reducers, and Ferroglobus placidus, which is capable of using ferrous iron, $\mathrm{H}_{2}$ and sulfide as electron donors with nitrate as electron acceptor [13]. Fig. 1 shows the phylogenetic affiliation of all current members of the 


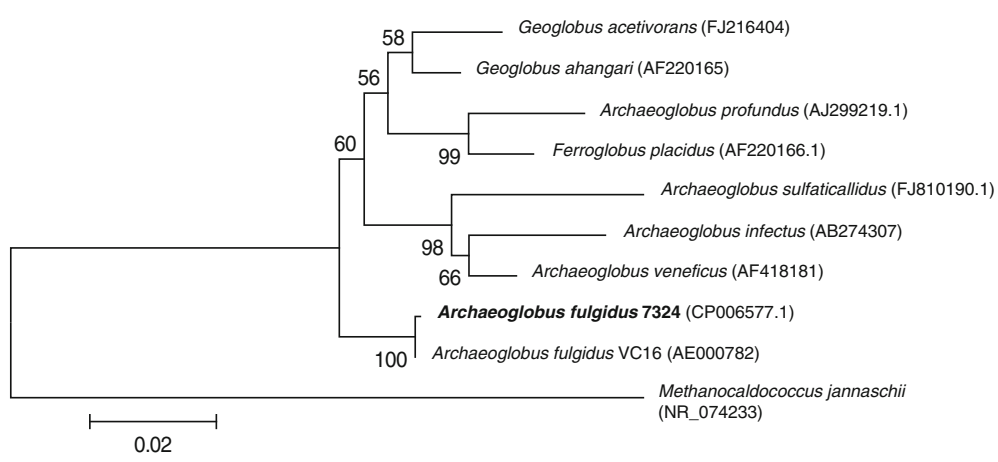

Fig. 116 S rRNA-based phylogenetic tree showing the position of the Archaeoglobus fulgidus strains within the Archaeoglobaceae family, using Methanocaldococcus jannaschii as outgroup. Only species with validly published names are included. The sequences were aligned using Clustal X [46] and the tree was inferred using the Neighbor-joining algorithm in MEGA 6.06 [47]. The bar indicated number of substitutions per site. Bootstrap values $\geq 60 \%$ are indicated at nodes and are based on 100 replicates. Sequence accession numbers are indicated in brackets. A. fulgidus strain 7324 is in bold

Archaeoglobaceae family, including strain 7324. All Archaeoglobus species form small irregularly shaped cells. A scanning electron micrograph of $A$. fulgidus strain 7324 is shown in Fig. 2, revealing a similar cell shape as originally determined by transmission electron microscopy [1]. Strain 7324 has not been phylogenetically characterized by $16 \mathrm{~S}$ rRNA gene sequencing before, but a wet lab genomic DNA: DNA hybridization with $A$. fulgidus strain $\mathrm{Z}$, which, like the type strain, was recovered from the Vulcano island [14], revealed a genome hybridization value of $100 \%$ [1]. This close relationship was now confirmed via digital DNA-DNA hybridization [15] between strains $\mathrm{VC}^{\mathrm{T}} 6^{\mathrm{T}}$ and 7324 with a GLM-based DDH estimate of $93.9 \%$. All three A. fulgidus strains share common physiological characteristics, like growth from $60{ }^{\circ} \mathrm{C}$ to above $84{ }^{\circ} \mathrm{C}$, use of sulfate and thiosulfate as electron acceptors, optimal growth with lactate or pyruvate as carbon sources, and production of trace amounts of methane. Although the

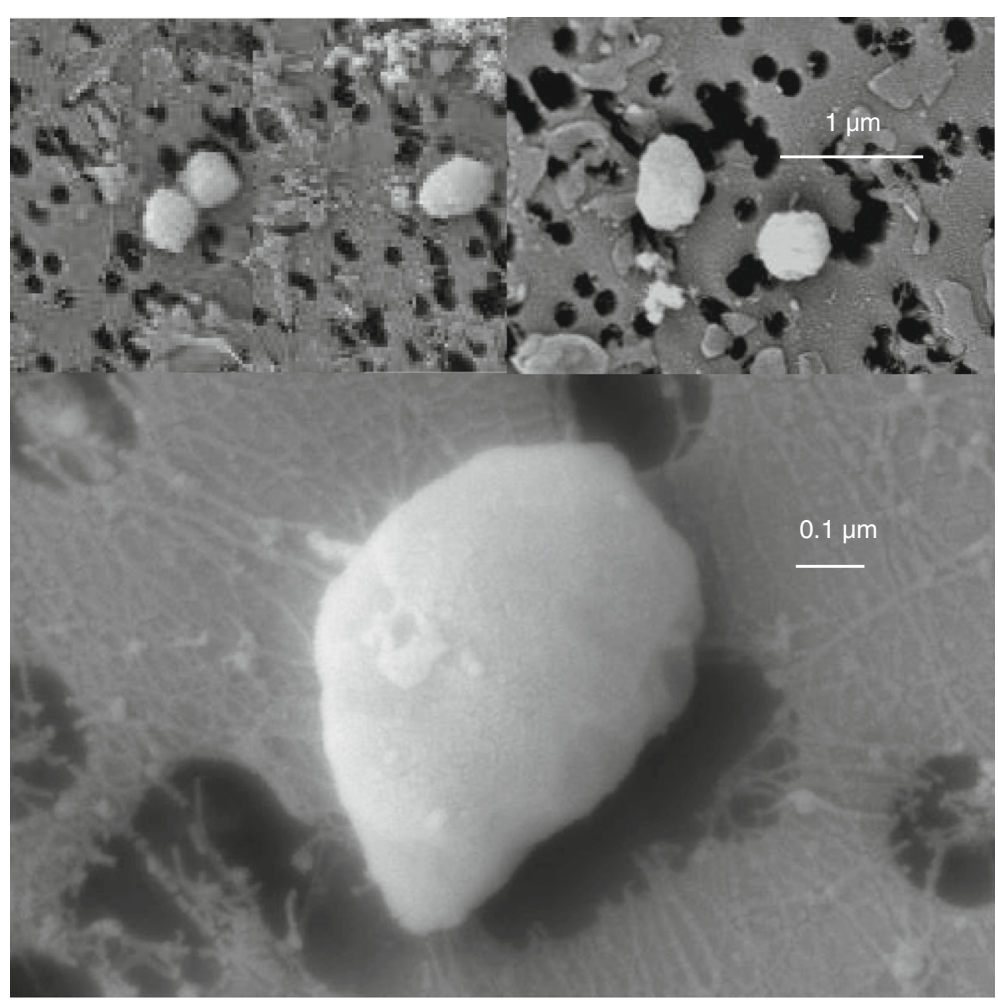

Fig. 2 Scanning electron micrographs of cells of A. fulgidus strain 7324. Bars equal $1 \mu \mathrm{m}$ (upper panel) or $0.1 \mu \mathrm{m}$ (lower panel) 
optimal growth temperature of strain 7324 was initially determined to $76{ }^{\circ} \mathrm{C}$, we have routinely been cultivating it at $80{ }^{\circ} \mathrm{C}$. In contrast to the other isolates, strain 7324 rapidly lyses after the stationary phase [1]. The main features of the organism are listed in Table 1.

\section{Genome sequencing information}

\section{Genome project history}

A. fulgidus strain 7324 was chosen for whole genome sequencing because it was isolated from a deep and hot oil reservoir while the closely related type strain, VC-16, was isolated from a shallow marine hot vent. A genome comparison might reveal particular adaptations of strain 7324 to the deep biosphere. The genome project information is given in the Genomes OnLine Database (Gp0102124). The genome sequence is deposited in GenBank (CP006577.1). A summary of the project information is shown in Table 2.

\section{Growth conditions and genomic DNA preparation}

A. fulgidus strain 7324 was from our own collection at the University of Bergen. It was cultivated in anaerobic medium containing lactate and sulfate as described previously [1]. The incubation temperature was $80{ }^{\circ} \mathrm{C}$. Genomic DNA was isolated using a modification of the cetyl trimethylammonium bromide method as described [16].

\section{Genome sequencing and assembly}

The genome was sequenced using a combination of Illumina and 454 sequencing platforms. All general aspects of library construction and sequencing can be found at the JGI website [17]. The initial assembly of 454 raw data suggested a contamination of the sequenced sample. Using blast search, all contigs (>500 nt in length) could be assigned either to A. fulgidus or Thermococcus litoralis, an archaeon that shares the same habitat [18]. To overcome this issue, two additional blast searches including all contigs longer than 500 nt were performed

Table 1 Classification and general features of Archaeoglobus fulgidus strain 7324 (DSM 8774)

\begin{tabular}{|c|c|c|c|}
\hline MIGS ID & Property & Term & Evidence code ${ }^{a}$ \\
\hline & Current classification & Domain Archaea & TAS [40] \\
\hline & & Phylum Euryarchaeota & TAS [41] \\
\hline & & Class Archaeoglobi & TAS [42] \\
\hline & & Order Archaeoglobales & TAS [43] \\
\hline & & Family Archaeoglobaceae & TAS [44] \\
\hline & & Genus Archaeoglobus & TAS [2] \\
\hline & & Species Archaeoglobus fulgidus & TAS [2] \\
\hline & & Strain 7324 & TAS [1] \\
\hline & Gram stain & Negative & IDA \\
\hline & Cell shape & Irregular coccoid to disc shaped & TAS [1] \\
\hline & Motility & Non-motile & TAS [1] \\
\hline & Sporulation & Nonsporulating & NAS \\
\hline & Temperature range & 60 to $85^{\circ} \mathrm{C}$ & TAS [1] \\
\hline & Optimum temperature & $76^{\circ} \mathrm{C}^{\mathrm{b}}$ & TAS [1] \\
\hline & Carbon source & Lactate, pyruvate, valerate & TAS [1] \\
\hline & Energy source & Lactate, pyruvate, valerate $+\mathrm{H}_{2}$ & TAS [1] \\
\hline & Terminal electron receptor & Sulfate and thiosulfate & TAS [1] \\
\hline MIGS-6 & Habitat & Deep oil-fields & TAS [1] \\
\hline MIGS-6.3 & Salinity & 3-500 mM NaCl (optimum at 300 mM) & TAS [1] \\
\hline MIGS-22 & Oxygen & Strictly anaerobic & TAS [1] \\
\hline MIGS-15 & Biotic relationship & Free-living & TAS [1] \\
\hline MIGS-14 & Pathogenicity & None & NAS \\
\hline MIGS-4 & Geographic location & Norway/North Sea & TAS [1] \\
\hline MIGS-5 & Sample collection time & 1993 or earlier & TAS [1] \\
\hline MIGS-4.3 & Depth & Subsurface & TAS [1] \\
\hline
\end{tabular}

aEvidence codes - IDA Inferred from Direct Assay, TAS Traceable Author Statement (i.e., a direct report exists in the literature), NAS, Non-traceable Author Statement (i.e., not directly observed for the living, isolated sample, but based on a generally accepted property for the species, or anecdotal evidence). These evidence codes are from the Gene Ontology project [45]

${ }^{\mathrm{b}}$ The strain grows well and has been routinely cultivated the last two decades in our labs at $80{ }^{\circ} \mathrm{C}$ 
Table 2 Project information

\begin{tabular}{|c|c|c|}
\hline MIGS ID & Property & Term \\
\hline MIGS 31 & Finishing quality & Finished \\
\hline MIGS-28 & Libraries used & $\begin{array}{l}454 \text { Titanium paired-end, Solexa paired } \\
\text { end }\end{array}$ \\
\hline MIGS 29 & $\begin{array}{l}\text { Sequencing } \\
\text { platforms }\end{array}$ & 454-GS-FLX, Solexa, Illumina \\
\hline MIGS 31.2 & Fold coverage & $103 x$ \\
\hline MIGS 30 & Assemblers & Newbler, Velvet v. 1.0.18; Consed v.20.0 \\
\hline \multirow[t]{6}{*}{ MIGS 32} & $\begin{array}{l}\text { Gene calling } \\
\text { method }\end{array}$ & GeneMark \\
\hline & Locus Tag & AFULGl \\
\hline & Genbank ID & СР006577.1 \\
\hline & $\begin{array}{l}\text { GenBank Date of } \\
\text { Release }\end{array}$ & 01.10 .2014 \\
\hline & GOLD ID & Gp0102124 \\
\hline & BIOPROJECT & PRJNA208006 \\
\hline \multirow[t]{2}{*}{ MIGS 13} & $\begin{array}{l}\text { Source Material } \\
\text { Identifier }\end{array}$ & DSM 8774 \\
\hline & Project relevance & $\begin{array}{l}\text { Environmental, evolution of anaerobic } \\
\text { respiration }\end{array}$ \\
\hline
\end{tabular}

against the previously sequenced genome of A. fulgidus VC-16 ${ }^{\mathrm{T}}$ (NCBI/GenBank:AE000782) and all available genomic sequences of Thermococcus species in Genebank (Dec. 2010). Only sequences in length sharing more than $90 \%$ sequence identity with A. fulgidus VC$16^{\mathrm{T}}$ and having no hits in the Thermococcus blast database were kept. A total of 84 Newbler contigs could be assigned to A. fulgidus. Illumina raw reads were assembled to 223 contigs. Both draft assemblies were merged in a hybrid approach using the phred/phrap/consed pipeline [19]. After manual curation, a total of 27 ordered gaps were closed by bridging PCRs at LGC Genomics (Berlin). The final consensus sequence represents a single circular chromosomal element (103× coverage).

\section{Genome annotation}

Coding genes were predicted by GeneMark [20] as part of the genome annotation pipeline in the Integrated $\mathrm{Mi}$ crobial Genomes Expert Review system [21]. The tRNAs were identified by tRNAScan-SE-1.23 [22], while ribosomal RNA genes within the genome were predicted using the tool RNAmmer [23]. Other non-coding RNA genes were predicted using Infernal [24]. CRISPR elements were identified by the program CRT [25]. Manual functional annotation was performed within the IMG platform [21] and the Artemis Genome Browser [26].

\section{Genome properties}

The genome of $A$. fulgidus strain 7324 comprises one circular chromosome with a total size of 2,316,287 bp, which is 137,887 bp larger than A. fulgidus $\mathrm{VC}^{-\mathrm{T}}{ }^{\mathrm{T}} \mathrm{DSM}$
3404 [3]. The mole percent $\mathrm{G}+\mathrm{C}$ is 48.08 , which is slightly higher than the $47 \%$ value estimated previously with thermal denaturation [1] and slightly lower than for the type strain DSM 3404 (48.6\%); in any case within the $1 \%$ threshold with the species' type strain $\mathrm{VC} 6^{\mathrm{T}}$ sensu Meier-Kolthoff et al. [27]. No plasmids were detected. The strain 7324 genome is the largest of the genomesequenced Archaeoglobus species, the smallest one being the A. profundus genome with a total size of $1.56 \mathrm{Mbp}$ [28]. Out of the total 2615 genes annotated in the 7324 genome, 2558 were identified as protein coding genes and 56 as RNA genes (Table 3). Only $67.29 \%$ of the genes could be assigned to COG functional categories as listed in Table 4. Five CRISPR repeat regions were identified, as compared with only three in strain $\mathrm{VC} 16^{\mathrm{T}}$ (AE000782). There is only one rRNA operon (Fig. 3). As for $\mathrm{VC}^{1} 6^{\mathrm{T}}$, there is no apparent $\mathrm{GC}$ skew in the genome, which could indicate the presence of multiple DNA replication origins and explain previous difficulties in precise mapping of replication origin(s) in this species using a marker rescue analysis approach $[29,30]$.

\section{Insights from the genome sequence}

Genes encoding central metabolic pathways like dissimilatory sulfate reduction, lactate oxidation, a complete TCA cycle and the Acetyl-CoA pathway were identified in strain 7324, confirming previous physiological characterization and similarity with strain $\mathrm{VC}^{\mathrm{T}} 6^{\mathrm{T}}$ [1]. A genome alignment between strains $\mathrm{VC} 6^{\mathrm{T}}$ and 7324 revealed a large degree of genomic similarity and sequence synteny, interrupted mostly by two large additional regions of about 64 and 109 Kbp (InsI and InsII, respectively) in strain 7324 as compared to $\mathrm{VC} 6^{\mathrm{T}}$ (Fig. 4). Both these regions are flanked by a

Table 3 Genome statistics

\begin{tabular}{lll}
\hline Attribute & Value & \% of Total \\
\hline Genome size (bp) & $2,316,287$ & $\mathrm{n} / \mathrm{a}$ \\
DNA coding (bp) & $2,077,792$ & 89.70 \\
DNA G + C (bp) & $1,113,590$ & 48.08 \\
DNA scaffolds & 1 & $\mathrm{n} / \mathrm{a}$ \\
Total genes & 2615 & 100 \\
Protein coding genes & 2558 & 97.86 \\
RNA genes & 56 & 2.14 \\
Pseudo genes & 1 & 0.04 \\
Genes in internal clusters & 342 & 13.08 \\
Genes with function prediction & 1880 & 71.89 \\
Genes assigned to COGs & 1759 & 67.29 \\
Genes with Pfam domains & 1982 & 75.82 \\
Genes with signal peptides & 80 & 3.06 \\
Genes with transmembrane helices & 490 & 18.75 \\
CRISPR repeats & 5 & $\mathrm{n} / \mathrm{a}$ \\
\hline
\end{tabular}


Table 4 Number of genes associated with general COG functional categories

\begin{tabular}{|c|c|c|c|}
\hline Code & Value & \%age & Description \\
\hline J & 195 & 10.3 & Translation, ribosomal structure and biogenesis \\
\hline A & 1 & 0.05 & RNA processing and modification \\
\hline K & 90 & 4.75 & Transcription \\
\hline L & 75 & 3.96 & Replication, recombination and repair \\
\hline B & 7 & 0.37 & Chromatin structure and dynamics \\
\hline $\mathrm{D}$ & 15 & 0.79 & Cell cycle control, Cell division, chromosome partitioning \\
\hline V & 68 & 3.59 & Defense mechanisms \\
\hline T & 54 & 2.85 & Signal transduction mechanisms \\
\hline M & 42 & 2.22 & Cell wall/membrane biogenesis \\
\hline $\mathrm{N}$ & 19 & 1 & Cell motility \\
\hline$U$ & 19 & 1 & Intracellular trafficking and secretion \\
\hline $\mathrm{O}$ & 68 & 3.59 & Posttranslational modification, protein turnover, chaperones \\
\hline C & 178 & 9.4 & Energy production and conversion \\
\hline G & 48 & 2.54 & Carbohydrate transport and metabolism \\
\hline E & 150 & 7.92 & Amino acid transport and metabolism \\
\hline $\mathrm{F}$ & 64 & 3.38 & Nucleotide transport and metabolism \\
\hline $\mathrm{H}$ & 138 & 7.29 & Coenzyme transport and metabolism \\
\hline I & 111 & 5.86 & Lipid transport and metabolism \\
\hline P & 82 & 4.33 & Inorganic ion transport and metabolism \\
\hline Q & 32 & 1.69 & Secondary metabolites biosynthesis, transport and catabolism \\
\hline $\mathrm{R}$ & 249 & 13.15 & General function prediction only \\
\hline S & 170 & 8.98 & Function unknown \\
\hline- & 855 & 32.71 & Not in COGs \\
\hline
\end{tabular}

disrupted tRNA gene, which implies that InsI and II represent genomic insertions. They also possess a considerably lower $\mathrm{G}+\mathrm{C}$ content (42\%) as compared to the average of the genome (Fig. 3), indicating a result of recombination with an AT-rich organism. This is further supported by identification of a non-coding high-GC RNA gene in InsII belonging to the $h g c C$ family of ncRNA (RFAM v12 accession code RF00062) typically found in AT-rich hyperthermophiles (Figs. 3 and 5b). This ncRNA family was originally identified in the genomes of Pyrococcus furiosus and Methanocaldococcus jannaschii [31] but its function is still unresolved.

InsII also contains a gene encoding an extra homologue of the Orc1/Cdc6 family of replication initiation control proteins in addition to the two other $c d c 6$ homologous in the 7324 and $\mathrm{VC} 6^{\mathrm{T}}$ genomes. The closest homologue identified by a blast search is from $A$. veneficus (62\% amino acid sequence identity). The majority of the other genes are hypothetical or have a general function prediction only. InsI carries two CRISPR repeat regions and 14 genes encoding CRISPRassociated proteins including a Cas6 homologue (Fig. 5a). The rest of this insert mostly contains hypothetical genes.
A Venn diagram shows that A. fulgidus strains $\mathrm{VC}^{\mathrm{T}}$ and 7324 share a large number of genes (2292) (Fig. 6a), reflecting the high degree of genome similarity. The 263 genes unique to strain 7324 include about 200 hypothetical genes/uncharacterized functions most of them belonging to the large insertions and the CRISPR-associated genes of InsII. The Venn diagram including all the five genome-sequenced strains revealed an Archaeoglobus core genome of 1001 genes (Fig. 6b), most of which encode energy-yielding, biosynthetic and regulatory functions. About 200 of the core genes belong to the hypothetical/ uncharacterized category in the EggNog database [32]. This is considerably lower than the $32 \%$ fraction of unassigned genes for the entire strain 7324 , but underpins that a large part of central gene functions in this genus still remain to be disclosed. About 2900 genes belong to the Archaeoglobus pan-genome, being unique to one of the genomes or shared by 2 to 4 of the species.

Archaeoglobus fulgidus strain 7324 has been reported to degrade starch [33] and several enzymes involved in starch degradation have been purified from cells grown on starch. These enzymes include cyclodextrin gluconotransferase, cyclodextrinase, maltodextrin phosphorylase, and phosphoglucomutase, ADP-dependent glucokinase, ADP-dependent 


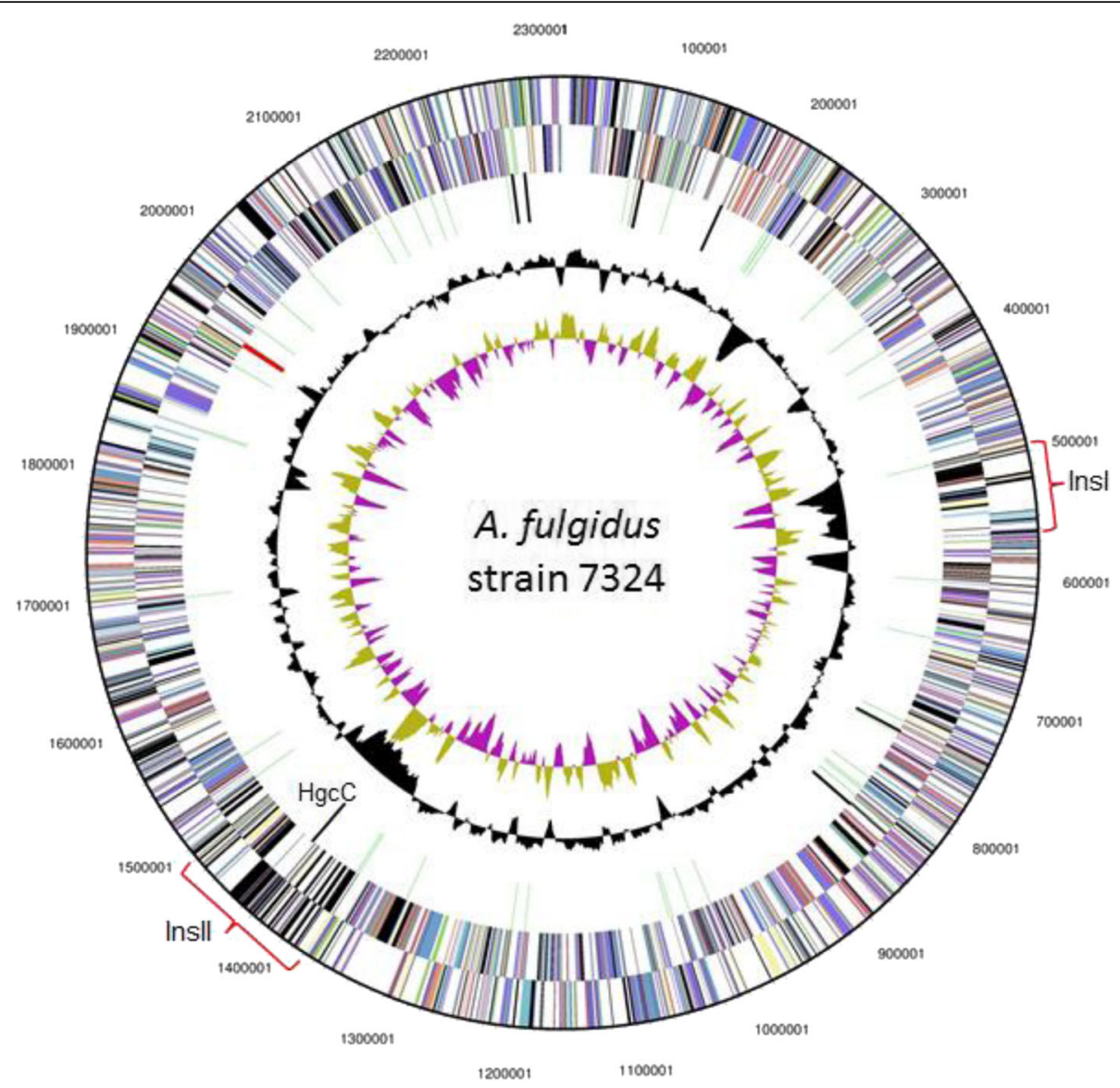

Fig. 3 Circular map of the A. fulgidus strain 7324 genome. From outside to the center: Genes on forward strand (colored by COG categories), genes on the reverse strand (colored by COG categories), RNA genes (tRNAs green, rRNAs red, other RNAs black), GC content, GC skew. The non-coding RNA gene, $h g c C$, is indicated, as well as the large insertions (denoted Insl and Insll), as compared to A. fulgidus VC16 ${ }^{\top}$

phosphofructokinase and pyruvate kinase [34-37]. The enzymes were biochemically characterized and the N-termini (with exception of cyclodextrinase) have been determined. They showed highest sequence identity to proteins from Thermococcales, e.g. from Thermococcus litoralis. However, in the genome of $A$. fulgidus presented here, genes encoding sugar degrading enzymes have not been identified. Rather, various analyses indicated that A. fulgidus strain 7324, deposited as DSM 8774, was contaminated with a Thermococcus strain. The genome of this Thermococcus strain has also been sequenced and all genes encoding the sugar degrading enzymes, originally attributed to A. fulgidus strain 7324, were found in the Thermococcus strain genome. Also, glutamate dehydrogenase from a DSM 8774 culture grown in the presence of small amounts of yeast extract $\left(0.3 \mathrm{gL}^{-}\right)$ was previously purified and characterized [38, 39], but

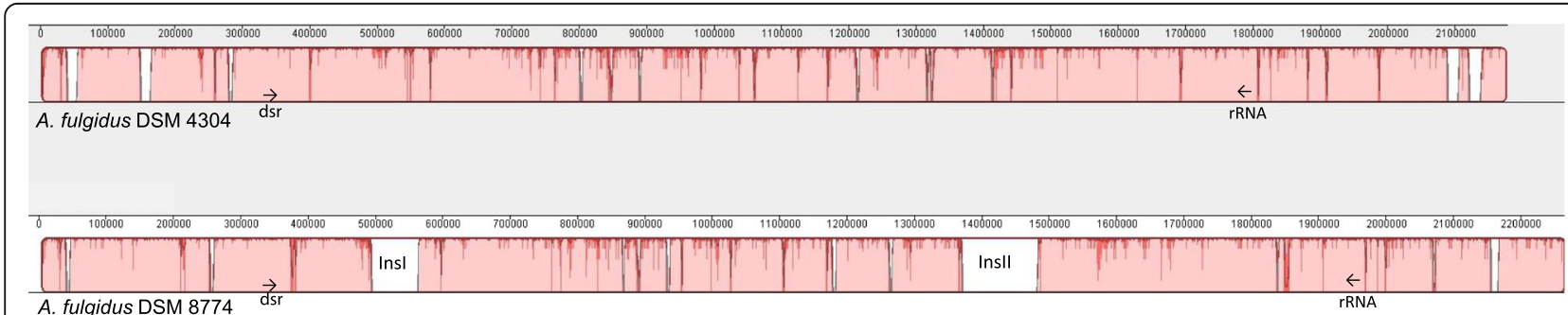

Fig. 4 MAUVE version 20,150,226 [48] alignment of the A. fulgidus strains VC-16 ${ }^{\top}$ (upper) and 7324 (lower) chromosomes. The large insertions in the 7324 chromosomes are indicated as regions InsI and Insll. Approximate positions of the rRNA and dsr (dissimilatory sulfite reductase) genes are indicated by arrows 


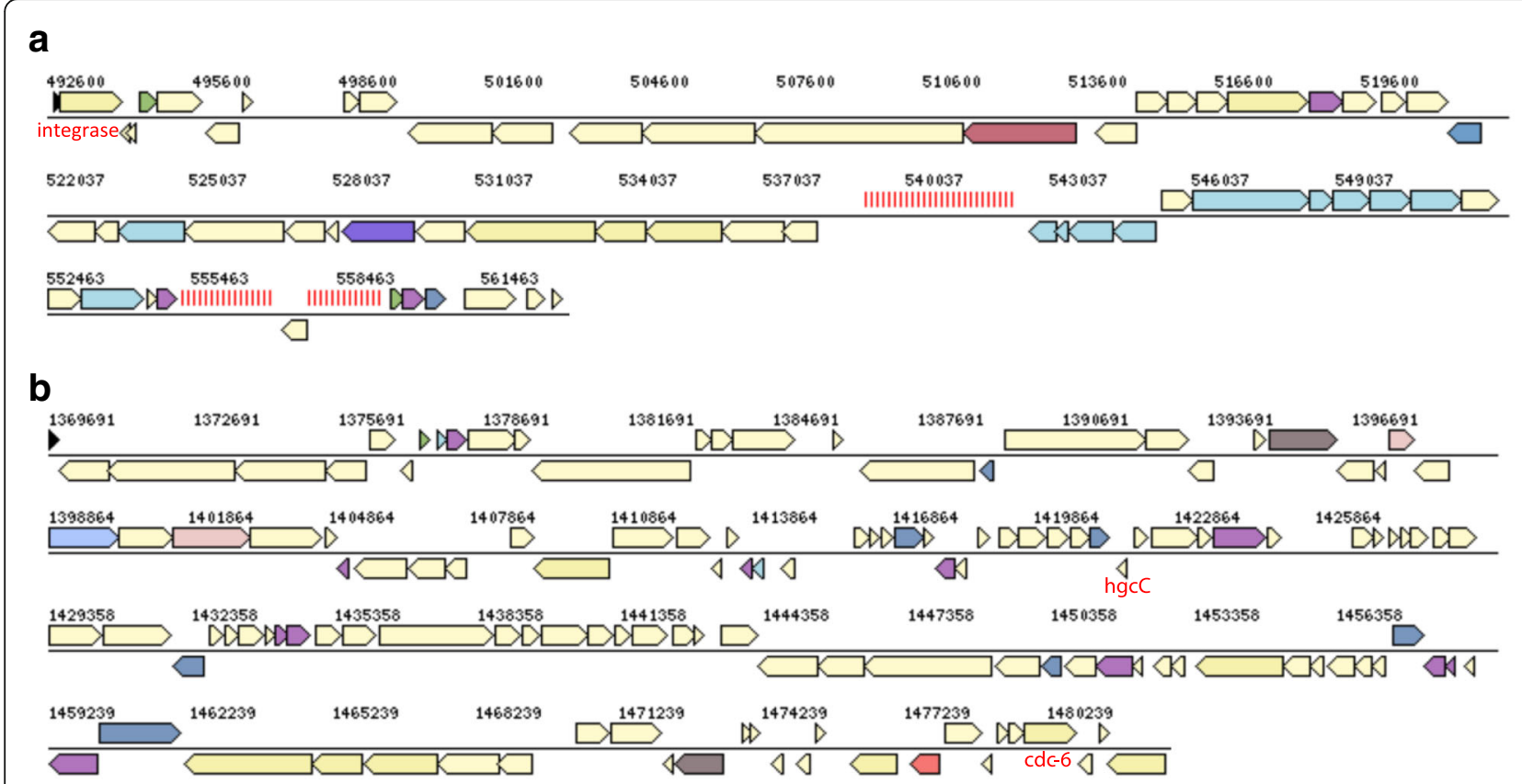

Fig. 5 Genetic structure of the large insertions in strain 7324; a Insl; b Insll. Genes are colored according to COG color codes

appears also to be encoded by the Thermococcus strain genome. The purity of the original A. fulgidus 7324 isolate was not assessed by $16 \mathrm{~S}$ rRNA gene sequencing prior to deposition at DSMZ [1] and whether the Thermococcus contamination was present in the original culture or has been introduced at a different stage is not known. The genome analysis of this Thermococcus strain, which appears to represent a novel Thermococcus species, will be published separately.

\section{Conclusions}

The complete genome of A. fulgidus strain 7324, recovered from hot water produced from an oil well in the North Sea was sequenced and annotated. In addition to the A. fulgidus type strain, VC16, isolated from a shallow hot vent in the Mediterranean, this is the second $A$. fulgidus genome to be characterized. The two strains share $93.5 \%$ genome sequence similarity, and differ mostly by two large insertions of 64 and $109 \mathrm{Kbp}$ in strain 7324 that seem to have originated from an AT-rich archaeon. The insertions carry two additional CRISPR elements, an extra $c d c 6$ gene, a variety of mobile genetic elements and a large number of hypothetical and unassigned genes. Based on comparison with four other Archaeoglobus spp. genomes, the Archaeoglobus core genome was estimated
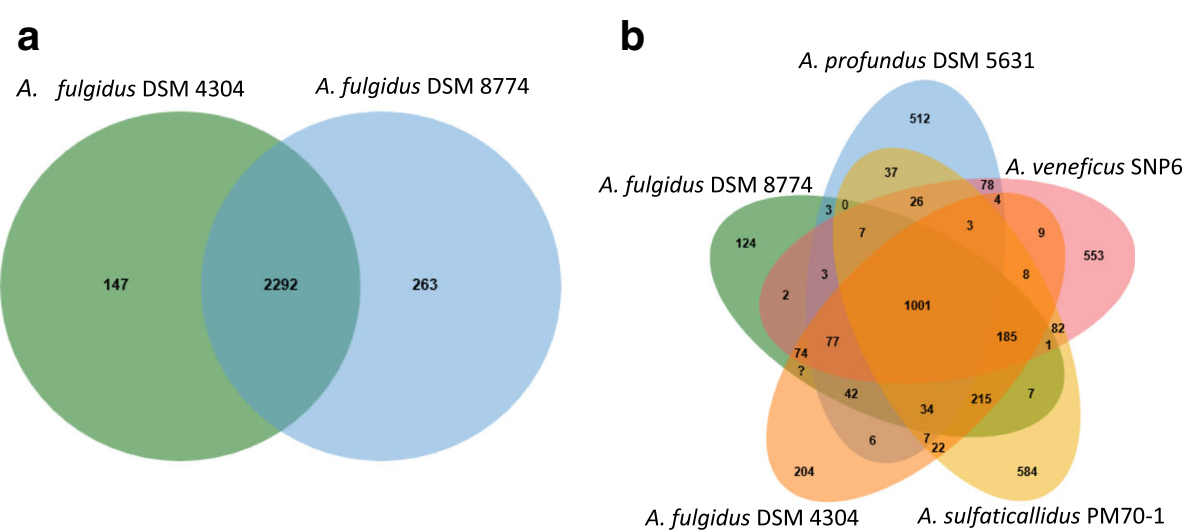

Fig. 6 Venn diagrams showing the distribution of orthologous and unique genes for a A. fulgidus strains DSM 4304 and DSM 8774, and $\mathbf{b}$ for all the completely genome sequenced Archaeoglobus representatives; A. fulgidus DSM 4305, A. fulgidus DSM 8774, Archaeoglobus profundus DSM 5631, Archaeoglobus veneficus DSM 11195 and Archaeoglobus sulfaticallidus DSM 19444. The diagrams were prepared using 'jvenn' [49] as implemented in the EzBioCloud's Comparative Genomics Database [50] 
to 1001 genes. No particular traits indicating adaptation to the petroleum reservoir subsurface environment could be identified.

\section{Authors' contributions}

NKB, PS and HPK conceived and designed this project, and were involved in interpretation of the data. NKB, HPK and AF performed the sequencing, assembly and the bioinformatics analysis. LP performed the electron microscopy. NKB prepared the first draft of the manuscript. All authors were involved in critical revision of the manuscript and approved the final version.

\section{Competing interests}

The authors declare that they have no competing interests.

\section{Publisher's Note}

Springer Nature remains neutral with regard to jurisdictional claims in published maps and institutional affiliations.

\section{Author details \\ 'Department of Biology, University of Bergen, P.O. Box 7803, NO-5020 Bergen, Norway. ${ }^{2}$ Institut für Allgemeine Mikrobiologie, Christian-Albrechts-Universität Kiel, 24118 Kiel, Germany. ${ }^{3}$ Leibniz-Institut DSMZ - German Collection of Microorganisms and Cell Cultures, Inhoffenstrasse 7b, 38124 Braunschweig, Germany. ${ }^{4}$ Present Address: IPK Gatersleben, Corrensstr. 3, 06466 Gatersleben, Germany. ${ }^{5}$ Present Address: School of Biology, Newcastle University, Newcastle upon Tyne NE1 7RU, UK}

Received: 24 July 2017 Accepted: 5 December 2017

Published online: 16 December 2017

\section{References}

1. Beeder J, Nilsen RK, Rosnes JT, Torsvik T, Lien T. Archaeoglobus fulgidus isolated from hot North Sea oil field waters. Appl Env Microbiol. 1994;60: 1227-31.

2. Stetter KO. Archaeoglobus fulgidus gen. nov., sp. nov, a new taxon of extremely thermophilic Archaebacteria. Syst Appl Microbiol. 1988;10:172-3.

3. Klenk HP, Clayton RA, Tomb JF, White O, Nelson KE, Ketchum KA, Dodson RJ, Gwinn M, Hickey EK, Peterson JD, et al. The complete genome sequence of the hyperthermophilic, sulphate-reducing archaeon Archaeoglobus fulgidus. Nature. 1997;390:364-70

4. Parey K, Fritz G, Ermler U, Kroneck PMH. Conserving energy with sulfate around 100 degrees $C$ - structure and mechanism of key metal enzymes in hyperthermophilic Archaeoglobus fulgidus. Metallomics. 2013;5:302-17.

5. Burggraf S, Jannasch HW, Nicolaus B, Stetter KO. Archaeoglobus profundus sp. nov., represents a new species within the sulfate-reducing Archaebacteria. Syst Appl Microbiol. 1990;13:24-8.

6. Huber H, Jannasch H, Rachel R, Fuchs T, Stetter KO. Archaeoglobus veneficus sp. nov., a novel facultative chemolithoautotrophic hyperthermophilic sulfite reducer, isolated from abyssal black smokers. Syst Appl Microbiol. 1997;20:374-80.

7. Mori K, Maruyama A, Urabe T, Suzuki Kl, Hanada S. Archaeoglobus infectus sp. nov., a novel thermophilic, chemolithoheterotrophic archaeon isolated from a deep-sea rock collected at Suiyo seamount, Izu-Bonin arc, western Pacific Ocean. Int J Syst Evol Micr. 2008;58:810-6.

8. Steinsbu BO, Thorseth $\mathrm{H}$, Nakagawa S, Inagaki F, Lever MA, Engelen B, Øvreas L, Pedersen RB. Archaeoglobus sulfaticallidus sp. nov., a thermophilic and facultatively lithoautotrophic sulfate-reducer isolated from black rust exposed to hot ridge flank crustal fluids. Int J Syst Evol Micr. 2010;60:2745-52.

9. Stetter KO, Huber R, Blochl E, Kurr M, Eden RD, Fielder M, Cash H, Vance I. Hyperthermophilic Archaea are thriving in deep North-Sea and Alaskan oilreservoirs. Nature. 1993;365:743-5.

10. Slobodkina GB, Kolganova TV, Querellou J, Bonch-Osmolovskaya EA, Slobodkin Al. Geoglobus acetivorans sp. nov., an iron(III)-reducing archaeon from a deep-sea hydrothermal vent. Int J Syst Evol Micr. 2009:59:2880-3.

11. Kashefi K, Tor JM, Holmes DE, Van Praagh CVG, Reysenbach AL, Lovley DR. Geoglobus ahangari gen. nov., sp. nov., a novel hyperthermophilic archaeon capable of oxidizing organic acids and growing autotrophically on hydrogen with Fe(III) serving as the sole electron acceptor. Int J Syst Evol Micr. 2002;52:719-28.
12. Tindall BJ, Euzeby JP. Status of strains that contravene rules 27 (3) and 30 of the international code of nomenclature of bacteria. Opinion 81. Int J Syst Evol Microbiol. 2008;58:1755-63.

13. Hafenbradl D, Keller M, Dirmeier R, Rachel R, Rossnagel P, Burggraf S, Huber H, Stetter KO. Ferroglobus placidus gen. nov., sp. nov., a novel hyperthermophilic archaeum that oxidizes $\mathrm{Fe}^{2+}$ at neutral $\mathrm{pH}$ under anoxic conditions. Arch Microbiol. 1996;166:308-14.

14. Zellner G, Stackebrandt E, Kneifel H, Messner P, Sleytr UB, Demacario EC, Zabel HP, Stetter KO, Winter J. Isolation and characterization of a thermophilic, sulfate reducing Archaebacterium, Archaeoglobus fulgidus strain-Z. Syst Appl Microbiol. 1989;11:151-60.

15. Meier-Kolthoff JP, Auch AF, Klenk HP, Göker M. Genome sequence-based species delimitation with confidence intervals and improved distance functions. BMC Bioinf. 2013; doi:10.1186/1471-2105-14-60.

16. Lien T, Madsen M, Rainey FA, Birkeland NK. Petrotoga mobilis sp. nov., from a North Sea oil-production well. Int J Syst Bacteriol. 1998;48:1007-13.

17. The DOE Joint Genome Institute. http://www.jgi.doe.gov. Accessed 15 Feb 2017.

18. Kostyukova AS, Gongadze GM, Polosina YY, Bonch-Osmolovskaya EA, Miroshnichenko ML, Chernyh NA, Obraztsova MV, Svetlichny VA, Messner P, Sleytr UB, et al. Investigation of structure and antigenic capacities of Thermococcales cell envelopes and reclassification of "Caldococcus litoralis" Z-1301 as Thermococcus litoralis Z-1301. Extremophiles. 1999;3:239-45.

19. Phrap, Phred and Consed for Windows, MacOS, Linux, and Unix. Www. phrap.com. Accessed 15 Feb 2017.

20. Besemer J, Borodovsky M. GeneMark: web software for gene finding in prokaryotes, eukaryotes and viruses. Nucleic Acids Res. 2005;33:451-4.

21. Markowitz VM, Mavromatis K, Ivanova NN, Chen IM, Chu K, Kyrpides NC. IMG ER: a system for microbial genome annotation expert review and curation. Bioinformatics. 2009;25:2271-8.

22. Hyatt D, Chen GL, Locascio PF, Land ML, Larimer FW, Hauser LJ. Prodigal: prokaryotic gene recognition and translation initiation site identification. BMC Bioinf. 2010; doi:10.1186/1471-2105-11-119.

23. Lagesen $K$, Hallin P, Rodland EA, Staerfeldt HH, Rognes T, Ussery DW. RNAmmer: consistent and rapid annotation of ribosomal RNA genes. Nucleic Acids Res. 2007;35:3100-8.

24. Nawrocki EP, Kolbe DL, Eddy SR. Infernal 1.0: inference of RNA alignments. Bioinformatics. 2009;25:1335-7.

25. Bland C, Ramsey TL, Sabree F, Lowe M, Brown K, Kyrpides NC, Hugenholtz P. CRISPR recognition tool (CRT): a tool for automatic detection of clustered regularly interspaced palindromic repeats. BMC Bioinf. 2007; doi:10.1186/ 1471-2105-8-209.

26. Rutherford K, Parkhill J, Crook J, Horsnell T, Rice P, Rajandream MA, Barrell B. Artemis: sequence visualization and annotation. Bioinformatics. 2000;16:944-5.

27. Meier-Kolthoff JP, Klenk HP, Göker M. Taxonomic use of DNA G+C content and DNA-DNA hybridization in the genomic age. Int J Syst Evol Microbiol. 2014;64:352-6.

28. von Jan M, Lapidus A, Del Rio TG, Copeland A, Tice H, Cheng JF, Lucas S, Chen F, Nolan M, Goodwin L, et al. Complete genome sequence of Archaeoglobus profundus type strain (AV18(T)). Stand Genomic Sci. 2010:2:327-46.

29. Maisnier-Patin S, Malandrin L, Birkeland NK, Bernander R. Chromosome replication patterns in the hyperthermophilic euryarchaea Archaeoglobus fulgidus and Methanocaldococcus (Methanococcus) jannaschiii (vol 45, pg 1443, 2001). Mol Microbiol. 2002:46:599.

30. Maisnier-Patin S, Malandrin L, Birkeland NK, Bernander R. Chromosome replication patternsin the hyperthermophilic euryarchaea Archaeoglobus fulgidus and Methanocaldococcus (Methanococcus) jannaschii. Mol Microbiol. 2002;45:1443-50.

31. Klein RJ, Misulovin Z, Eddy SR. Noncoding RNA genes identified in AT-rich hyperthermophiles. P Natl Acad Sci USA. 2002;99:7542-7.

32. Huerta-Cepas J, Szklarczyk D, Forslund K, Cook H, Heller D, Walter MC, Rattei T, Mende DR, Sunagawa S, Kuhn M, et al. eggNOG 4.5: a hierarchical orthology framework with improved functional annotations for eukaryotic, prokaryotic and viral sequences. Nucleic Acids Res. 2016:44:286-93.

33. Labes A, Schönheit P. Sugar utilization in the hyperthermophilic, sulfatereducing archaeon Archaeoglobus fulgidus strain 7324: starch degradation to acetate and $\mathrm{CO} 2$ via a modified Embden-Meyerhof pathway and acetyl-CoA synthetase (ADP-forming). Arch Microbiol. 2001;176:329-38.

34. Hansen T, Schönheit P. ADP-dependent 6-phosphofructokinase, an extremely thermophilic, non-allosteric enzyme from the hyperthermophilic, sulfate-reducing archaeon Archaeoglobus fulgidus strain 7324. Extremophiles. 2004;8:29-35.

35. Johnsen U, Hansen T, Schönheit P. Comparative analysis of pyruvate kinases from the hyperthermophilic archaea Archaeoglobus fulgidus, Aeropyrum 
pernix, and Pyrobaculum aerophilum and the hyperthermophilic bacterium Thermotoga maritima - unusual regulatory properties in hyperthermophilic archaea. J Biol Chem. 2003;278:25417-27.

36. Labes A, Schönheit P. ADP-dependent glucokinase from the hyperthermophilic sulfate-reducing archaeon Archaeoglobus fulgidus strain 7324. Arch Microbiol. 2003;180:69-75.

37. Labes A, Schönhelt P. Unusual starch degradation pathway via cyclodextrins in the hyperthermophilic sulfate-reducing archaeon Archaeoglobus fulgidus strain 7324. J Bacteriol. 2007;189:8901-13.

38. Aalen N, Steen $\mathbb{H}$, Birkeland NK, Lien T. Purification and properties of an extremely thermostable NADP(+)-specific glutamate dehydrogenase from Archaeoglobus fulgidus. Arch Microbiol. 1997;168:536-9.

39. Steen IH, Hvoslef $H$, Lien T, Birkeland NK. Isocitrate dehydrogenase, malate dehydrogenase, and glutamate dehydrogenase from Archaeoglobus fulgidus. Method Enzymol. 2001:331:13-26.

40. Woese CR, Kandler O, Wheelis ML. Towards a natural system of organisms: proposal for the domains Archaea, bacteria, and Eucarya. Proc Natl Acad Sci U S A. 1990;87:4576-9.

41. Garrity GM, Holt JG. Phylum All. Euryarchaeota phy. nov. In: Garrity GM, Boone DR, Castenholz RW, editors. Bergey's manual of systematic bacteriology, second edition, volume 1. New York: Springer; 2001. p. 211355.

42. Garrity GM, Holt JG. Class VI. Archaeoglobi class. nov. In: Garrity GM, Boone DR, Castenholz RW, editors. Bergey's manual of systematic bacteriology, second edition, volume 1. The Archaea and the deeply branching and phototrophic Bacteria. New York: Springer; 2001. p. 349

43. Huber H, Stetter KO. Order I. Archaeoglobales ord. nov. In: Garrity GM, Boone DR, Castenholz RW, editors. Bergey's manual of systematic bacteriology, second edition, volume 1. The Archaea and the deeply branching and phototrophic Bacteria. New York: Springer; 2001. p. 349

44. Huber H, Stetter KO. Family I. Archaeoglobaceae fam. nov. In: Garrity GM, Boone DR, Castenholz RW, editors. Bergey's manual of systematic bacteriology, second edition, volume 1. The Archaea and the deeply branching and phototrophic Bacteria. New York: Springer; 2001. p. 349.

45. Ashburner M, Ball CA, Blake JA, Botstein D, Butler H, Cherry JM, Davis AP, Dolinski K, Dwight SS, Eppig JT, et al. Gene ontology: tool for the unification of biology. Nat Genet. 2000;25:25-9.

46. Larkin MA, Blackshields G, Brown NP, Chenna R, McGettigan PA, McWilliam $H$, Valentin F, Wallace IM, Wilm A, Lopez R, et al. Clustal W and clustal X version 2.0. Bioinformatics. 2007;23:2947-8.

47. Tamura K, Stecher G, Peterson D, Filipski A, Kumar S. MEGA6: molecular evolutionary genetics analysis version 6.0. Mol Biol Evol. 2013;30:2725-9.

48. Darling ACE, Mau B, Blattner FR, Perna NT. Mauve: multiple alignment of conserved genomic sequence with rearrangements. Genome Res. 2004;14 1394-403.

49. Bardou P, Mariette J, Escudie F, Djemiel C, Klopp C. jvenn: an interactive Venn diagram viewer. BMV. Bioinformatics. 2014;15 doi:10.1186/1471-210515-293.

50. EzBioCloud's Comparative Genomics Database. https://www.ezbiocloud.net/. Accessed 15 Mar 2017

\section{Submit your next manuscript to BioMed Central and we will help you at every step:}

- We accept pre-submission inquiries

- Our selector tool helps you to find the most relevant journal

- We provide round the clock customer support

- Convenient online submission

- Thorough peer review

- Inclusion in PubMed and all major indexing services

- Maximum visibility for your research

Submit your manuscript at www.biomedcentral.com/submit
Biomed Central 